\title{
ADSORBENTS FOR IRON REMOVAL OBTAINED FROM VERMICULITE
}

\author{
Agnieszka WEGRZYN ${ }^{1)}{ }^{*}$, Lucjan CHMIELARZ ${ }^{1)}$, Pawel ZJEŻDŻALKA ${ }^{1)}$, Andrzej KOWALCZYK ${ }^{1)}$, \\ Magdalena JABŁOŃSKA ${ }^{1 \text {, }}$, Xavier BALDRICH TOLOSA ${ }^{2)}$ and Marek MICHALIK ${ }^{3)}$
}

\author{
1) Jagiellonian University, Faculty of Chemistry, Ingardena 3, 30-060 Kraków, Poland, Phone: 12 6336377, \\ Fax: 126340515 \\ 2) Universitat de Barcelona, Facultat de Quimica, Martí i Franquès, 1-11, 08028 Barcelona, Espanya, \\ Phone: 9340212 00, Fax: 934111492 \\ 3) Jagiellonian University, Institute of Geological Sciences, Oleandry 2a, 30-063 Kraków, Phone: 126632495 , \\ Fax: 126332270 \\ *Corresponding author's e-mail: a.m.wegrzyn@uj.edu.pl
}

(Received March 2013, accepted July 2013)

\begin{abstract}
In presented work, raw, expanded and acid treated vermiculites were used as low-cost and active adsorbents for reducing of environmental pollution with heavy metals. Acid treatment was performed at elevated temperature $\left(95^{\circ} \mathrm{C}\right)$ for 2 and $24 \mathrm{~h}$ in solution of $\mathrm{HNO}_{3}$. Adsorption capacity towards $\mathrm{Fe}^{3+}$ was studied in column, semi-batch and batch mode. It was shown that all samples are effective in removal of heavy metals; however adsorption mechanism is based not only on ion exchange of interlayer cations but also precipitation/deposition processes. Starting material and modified samples as well as spent adsorbents were characterized with respect to the vermiculite structure using X-ray diffraction method.
\end{abstract}

KEYWORDS: vermiculite, acid treatment, iron removal, adsorption

\section{INTRODUCTION}

The quality of water is essential to the maintenance of a healthy hydrological environment and to human health. In accordance to the water framework directive 2000/60/CE and subsequent changes, 2006/11/CE and 2008/32/CE (EU Water Framework Directive), emissions of priority substances should be eliminated. There are two groups of water pollutants of particular interest: refractory organic compounds and heavy metals. During past decades, several physical, chemical and biological methods for pollutants neutralization have been developed. Nevertheless, all of them have their inherent advantages and drawbacks.

Heavy metals, usually present in industrial wastewaters, are toxic, non-biodegradable, and may be bio-accumulated in living tissues. Among different technologies currently coagulation and flocculation are used frequently. Combined with flotation and filtration (electrofiltration, electrochemical processes, precipitation, etc.) they are simple and economically acceptable methods. However, accumulation of concentrated sludge creates a disposal problem as well as high initial cost, high maintenance and operational cost. High consumption of chemicals may result in secondary pollution problem. Precipitation of metal hydroxides or sulfides, besides of large volumes of low density sludge, may be problematic in a mixture of amphoteric metals and in presence of chelating agents. In the case of sulfides, precise regulation of $\mathrm{pH}$ is required due to possibility of toxic $\mathrm{H}_{2} \mathrm{~S}$ evolution. Application of biological treatment, which is the most publicly acceptable and economical method, is limited because of technical constrains. It requires large area, process is slow, operational flexibility is low and maintenance - complicated. Moreover, microorganisms have high nutrition requirements and xenobiotic molecules cannot be totally degraded. Physical methods, such as membrane-filtration, reverse osmosis and electrodialysis are usually based on very expensive materials, and cannot handle large volumes of waste-water. The weakness of the aforementioned methods is also high power consumption. On the other hand, another physical process - adsorption is much more effective and economical. Facing more and more stringent environmental regulations, new waste-free technologies must be developed, based on cheaper, non-toxic materials. Clays proposed as starting materials fulfill all requirements for low-cost, ecological precursors for industrial technologies or large scale applications (Fu and Wang, 2011; Crini, 2006; Forgacs et al., 2004; Sumathi et al., 2005).

Vermiculite is natural clay mineral with layered structure. It consists of octahedral alumina or magnesia sandwiched between two tetrahedral silicate sheets. Net negative charge is compensated by interlayer cations such as $\mathrm{K}^{+}, \mathrm{Mg}^{2+}, \mathrm{Fe}^{3+}$. Due to low cost and availability raw mineral has been exploited in many applications: accumulation of water, adsorption of heavy metals, oil, humic acids and pesticides (Vieira dos Santos and Masini, 2007; Abate et al., 


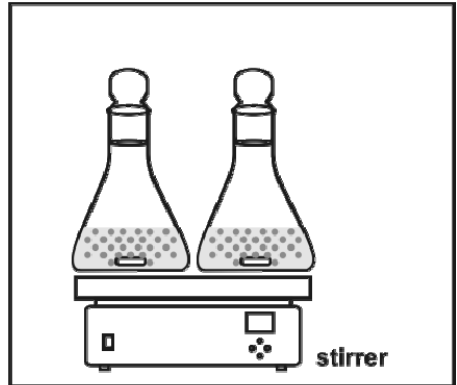

BATCH REACTOR

+ simple arrangement

- difficult separation and possibility of mechanical degradation of the adsorbent

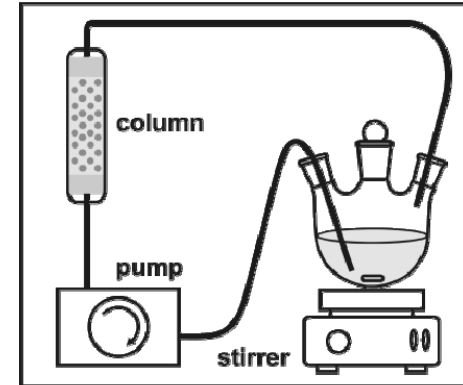

SEMI-BATCH REACTOR

+ easy separation of the adsorbent

+ easy control of process parameters

- requirement of pump

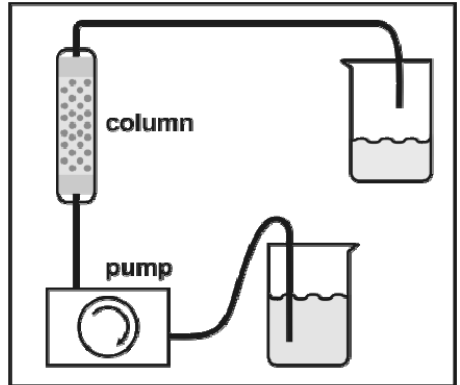

COLUMN REACTOR

+ easy separation of the adsorbent

- requirement of pump

- strict control of flow rate

Fig. 1 Experimental set-up for adsorption in batch, semi-batch and column mode.

2006; Malandrino et al., 2006; da Fonseca et al., 2005). However, as it is in the case of other clays and clay minerals, many techniques, such as: pillaring with polycations, modification with organic compounds or selective leaching, were proposed to improve chemical properties of the mineral, its morphology and texture both for applications in catalysis and adsorption (Abate et al., 2006; Machado et al., 2006; Zhao et al., 2008; Chmielarz et al., 2009; Yu et al., 2010).

The research data suggest that mechanism of heavy metal removal from waste waters using vermiculite is governed by ion exchange. The process efficiency may be also influenced by the presence of other cations and ligands (Malandrino et al., 2006; da Fonseca et al., 2006; Abollino et al., 2008; El-Bayaa et al., 2009). In presented work another hypothesis of possible adsorption mechanism is tested - deposition/precipitation of polymeric species on the surface and in interlayer galleries. In presented work solution containing $\mathrm{Fe}^{3+}$ was used as a model adsorbate for heavy metals removal process.

\section{EXPERIMENTAL}

\subsection{MATERIALS AND CHARACTERIZATION}

Commercial raw (VA0) and expanded (VAe0) vermiculite (South Africa), fraction size $1 \mathrm{~mm}$, was provided by Romico Polska Sp. z o.o. Expanded vermiculite was used as a starting material for preparation of acid modified samples according to the following procedure:

- $100 \mathrm{~mL}$ of $0.8 \mathrm{M} \mathrm{HNO}_{3}$ was placed in roundbottom flask equipped with reflux condenser and its temperature was raised to $95^{\circ} \mathrm{C}$,

- $10 \mathrm{~g}$ of vermiculite (VAe0) was added to hot solution of acid and kept stirring at elevated temperature for 2 or $24 \mathrm{~h}$ (sample names: VAeN2 and VAeN24, respectively),

- vermiculite flakes were filtered and washed with distilled water, then both samples were dried at room temperature.
The structure of raw, expanded and acid treated as well as spent samples was studied using X-ray powder diffractometer (Bruker, D2 PHASER) equipped with $\mathrm{CuK}_{\alpha}$ radiation source.

\subsection{ADSORPTION EXPERIMENTS}

Adsorption of $\mathrm{Fe}^{3+}$ as a model metal cation was studied in 3 different modes: batch, semi-batch and column (Fig. 1). In all experiments sample VAe0 was used as received from company, additionally in semibatch and column experiments adsorbent was diluted (1:10) with quartz sand. The following parameters were set for experiments:

- concentration range: 0.00012-0.002 $\mathrm{mol} \mathrm{Fe}^{3+} / \mathrm{L}$,

- flow rate: semi-batch $100 \mathrm{~mL} / \mathrm{min}$, column 2.8 $2.4 \mathrm{~mL} / \mathrm{min}$,

- solution/adsorbent ratio: batch/semi-batch: $200 \mathrm{~mL} / 0.25 \mathrm{~g}$, column: $400 \mathrm{ml} / 0.25 \mathrm{~g}$,

- temperature: $25^{\circ} \mathrm{C}$,

- $\mathrm{pH}=3.5$ (adjusted with acetate buffer).

In batch mode experiments with different adsorbents were performed at the following conditions:

- $\quad$ samples: VA0, VAe0, VAeN2, VAeN24,

- concentration range: 0.0015-0.0054 $\mathrm{mol} \mathrm{Fe}^{3+} / \mathrm{L}$,

- solution/adsorbent ratio: batch: $100 \mathrm{~mL} / 0.125 \mathrm{~g}$,

- temperature: $25^{\circ} \mathrm{C}$

- $\mathrm{pH}=3.5$, acetate buffer $0.2 \mathrm{M}$.

\section{RESULTS AND DISCUSSION}

\subsection{CHARACTERIZATION OF FRESH ADSORBENTS}

The X-ray diffraction (XRD) patterns of all adsorbents are presented in Figure 2. The intensity of recorded peaks of raw vermiculite (VA0) was decreased 10 times to make easier comparison between all samples. Natural raw vermiculite - as received from the company, is characterized with highly ordered structure. All reflections are sharp and 

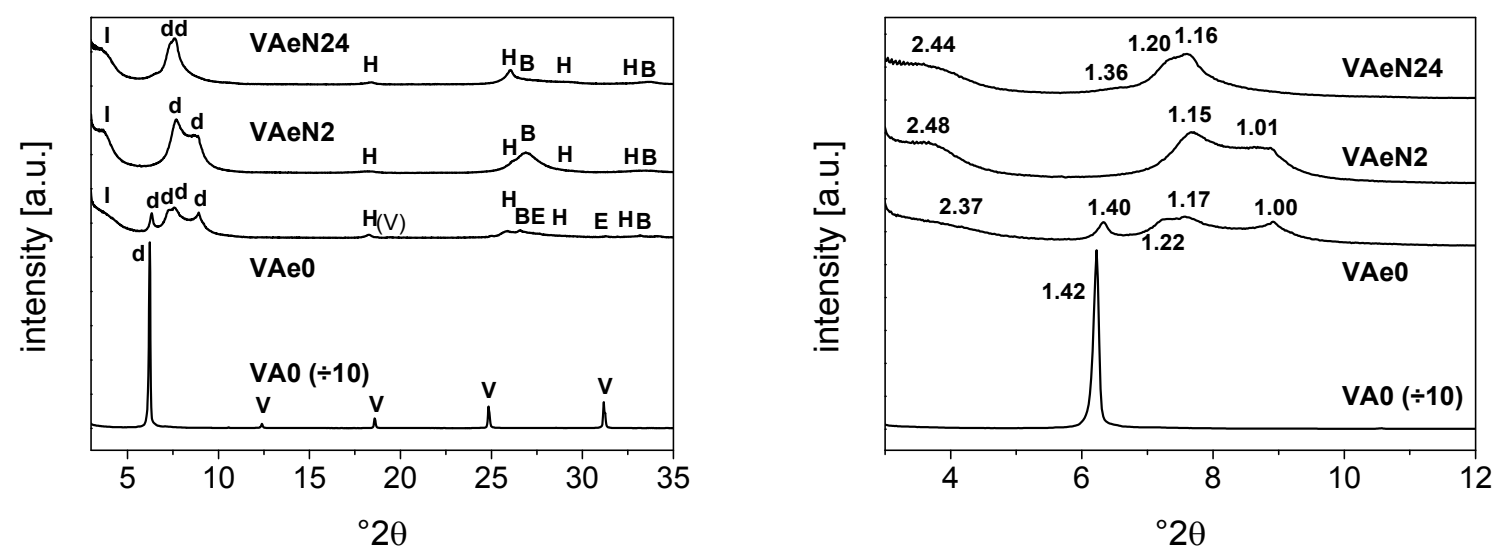

Fig. 2 XRD patterns of raw (VA0), expanded (VAe0) and acid treated (VAeN2, VAeN24) vermiculites; Iinterstratified phase, $\mathrm{H}$ - hydrobiotite, $\mathrm{B}$ - biotite, $\mathrm{V}$ - vermiculite:, $\mathrm{E}$ - enstatite, $\mathrm{d}$ - basal reflections.

Table 1 Interlayer distances of raw (VA0), expanded (VAe0) and acid treated (VAeN2, VAeN24) vermiculites.

\begin{tabular}{c|c|c|c|c|c}
\hline sample name & $\mathrm{d}[\mathrm{nm}]$ & $\mathrm{d}[\mathrm{nm}]$ & $\mathrm{d}[\mathrm{nm}]$ & $\mathrm{d}[\mathrm{nm}]$ & $\mathrm{d}[\mathrm{nm}]$ \\
\hline VA0 & - & 1.42 & - & - & - \\
VAe0 & 2.37 & 1.40 & 1.22 & 1.17 & 1.00 \\
VAeN2 & 2.48 & - & - & 1.15 & 1.01 \\
VAeN24 & 2.44 & 1.36 & 1.20 & 1.16 & - \\
\hline & inter-stratification & $\begin{array}{c}\text { 2 layers of water } \\
\mathrm{Mg}^{2+} / \mathrm{Fe}^{3+}\end{array}$ & $\begin{array}{c}\text { inter- } \\
\text { stratification }\end{array}$ & $\begin{array}{c}1 \text { layer of water } \\
\mathrm{Mg}^{2+} / \mathrm{Fe}^{3+}\end{array}$ & $\begin{array}{c}0 \text { layers of water } \\
\mathrm{H}_{3} \mathrm{O}^{+}\left(\mathrm{K}^{+}\right)\end{array}$ \\
\hline
\end{tabular}

very intense and confirm presence of vermiculite (Gordeeva et al., 2002; da Fonseca et al., 2006; Marcos et al., 2009). No side-phases or impurities were identified. On the contrary, expanded material (VAe0) is characterized with complex phase composition. Two main phases were identified: hydrobiotite (peaks of high intensity at 1.223, 0.349, $0.491,0.272 \mathrm{~nm}$ ) (Downs, 2006) and biotite (peaks of high intensity at $1.01,0.337,0.266 \mathrm{~nm}$ ) (Downs, 2006). Probably traces of vermiculite could be also detected as well as enstatite. Moreover, it cannot be excluded that mica-like structure, probably muscovite, was formed (Marcos et al., 2009; Marcos et al., 2010). In acid treated samples both hydrobiotite and biotite were also identified, although the former phase is dominating in the sample treated for longer time (VAeN24) and the latter one in the sample treated only for $2 \mathrm{~h}$ (VAeN2). It cannot be excluded that material contains also amorphous silica which is formed due to leaching of phyllosilicale layers (Chmielarz et al., 2010; Chmielarz et. al., 2012).

In each sample several basal reflections were identified (Table 1.). In the case of raw vermiculite VA0 calculated interlayer space value was indicating the presence of 2 layers of water, characteristic for such cation as $\mathrm{Mg}^{2+}$ or $\mathrm{Fe}^{3+}$ (Helsen, 1975; Argüelles et al., 2011). For expanded vermiculite the presence of 2,1 or 0 layers of water molecules in the domains of the layered structure is typical. In acid treated samples diversity of basal spacings is limited due to successful ion exchange for hydronium cations (Chmielarz et al., 2010; Chmielarz et. al., 2012). However, it should be noted that extensive acid treatment results in dissolution of octahedral sheet and released cations may also occupy interlayer galleries.

\subsection{ADSORPTION IN BATCH, SEMI-BATCH AND COLUMN MODE}

All the performed experiments showed that expanded vermiculite adsorbs significant amount of $\mathrm{Fe}^{3+}$. Kinetic curves for each type of set-up are presented in Figure 3. In batch/semi-batch experiments only at low $\mathrm{Fe}^{3+}$ concentrations equilibrium was reached in 120 minutes (total time of adsorption). At higher concentrations adsorbed amount was still increasing. Both isotherms presented in Figure 3. show that monolayer coverage has been not reached. Also in the case of column experiment at higher concentration full saturation of adsorbent is questionable after feeding about $350 \mathrm{~mL}$ of the solution containing $\mathrm{Fe}^{3+}$ cations. The best method, resulting in highest removal degree and easy operation was semi-batch method. Based on estimated adsorption capacities, it might be concluded that in order to reach higher level of purification a combination of batch or semi-batch mode with column mode might be employed. Semi-batch and batch modes perform better with higher concentrated 


\section{BATCH}

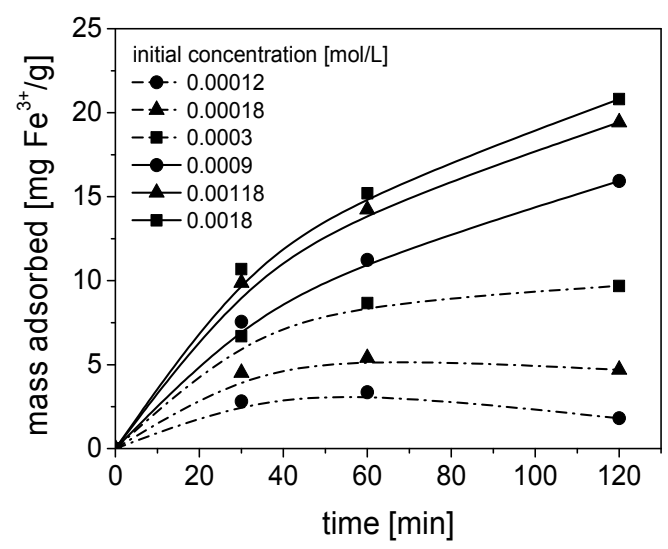

\section{SEMI-BATCH}

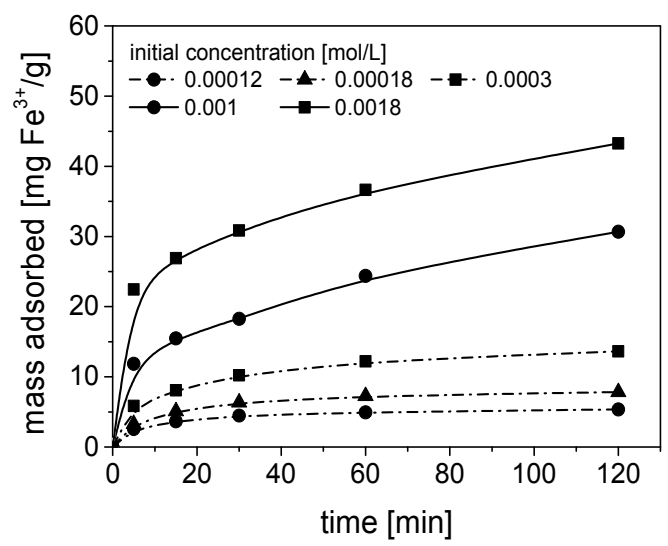

\section{COLUMN}

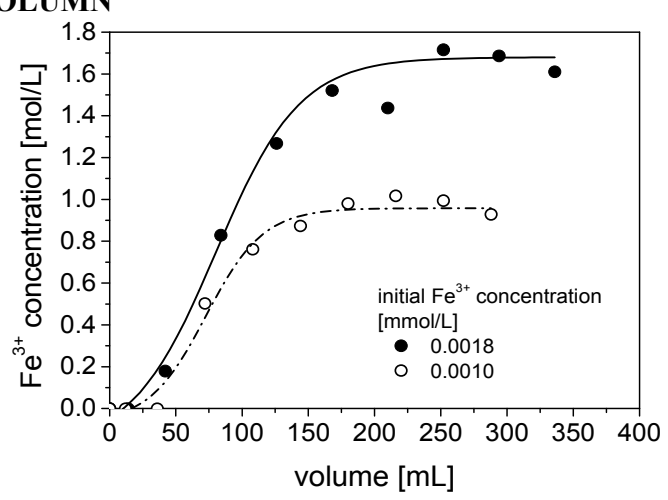

\section{ВАТСН}

adsorption capacity $(2 \mathrm{~h})$ :

$21 \mathrm{mg} \mathrm{Fe}^{3+} / \mathrm{g}, 0.376 \mathrm{mmol} \mathrm{Fe}^{3+} / \mathrm{g}$

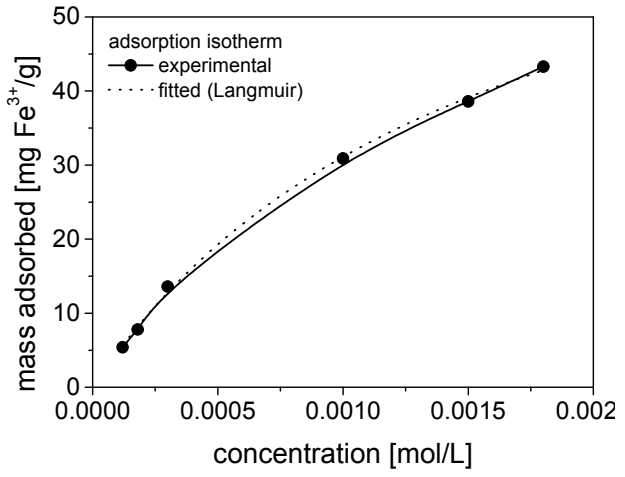

\section{SEMI-BATCH}

adsorption capacity $(2 \mathrm{~h})$ :

$45 \mathrm{mg} \mathrm{Fe}^{3+} / \mathrm{g}, 0.806 \mathrm{mmol} \mathrm{Fe}^{3+} / \mathrm{g}$

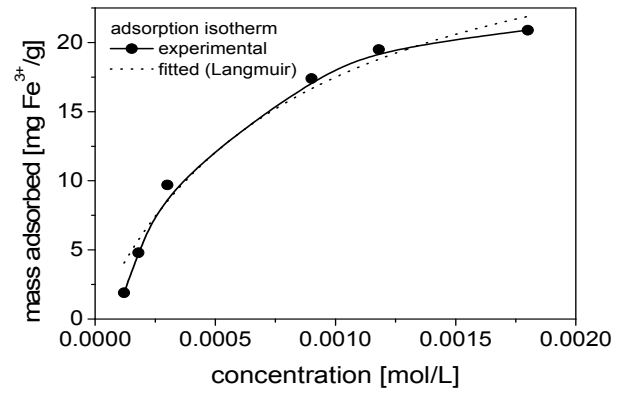

\section{COLUMN}

adsorption capacity

(at concentration $0.0018 \mathrm{~mol} / \mathrm{L}$ ):

$32 \mathrm{mg} \mathrm{Fe}^{3+} / \mathrm{g}, 0.58 \mathrm{mmol} \mathrm{Fe}^{3+} / \mathrm{g}$

Fig. 3 Results of iron adsorption on expanded vermiculite VAe0: kinetic curves of $\mathrm{Fe}^{3+}$ adsorption on expanded vermiculite for batch, semi-batch and column mode (left); isotherms and maximum adsorption capacities measured for the sample VAe0 (right).

solutions, thus they would be used as a pre-treatment unit. The process would be then accomplished in column which work is satisfactory with relatively low concentrated solutions. However, batch mode is less desired option than semi-batch, because in batch mode additional separation equipment is required before entering the column - that makes the process more expensive.

\subsection{COMPARISON OF PROPERTIES OF DIFFERENT ADSORBENTS}

A series of batch experiments was performed in order to compare adsorption properties of raw (VA0), expanded (VAe0) and acid treated (VAeN2, VAeN24) vermiculites (Fig. 4). Based on previous measurements broader range of concentrations as well as longer adsorption time was applied - concentration of 

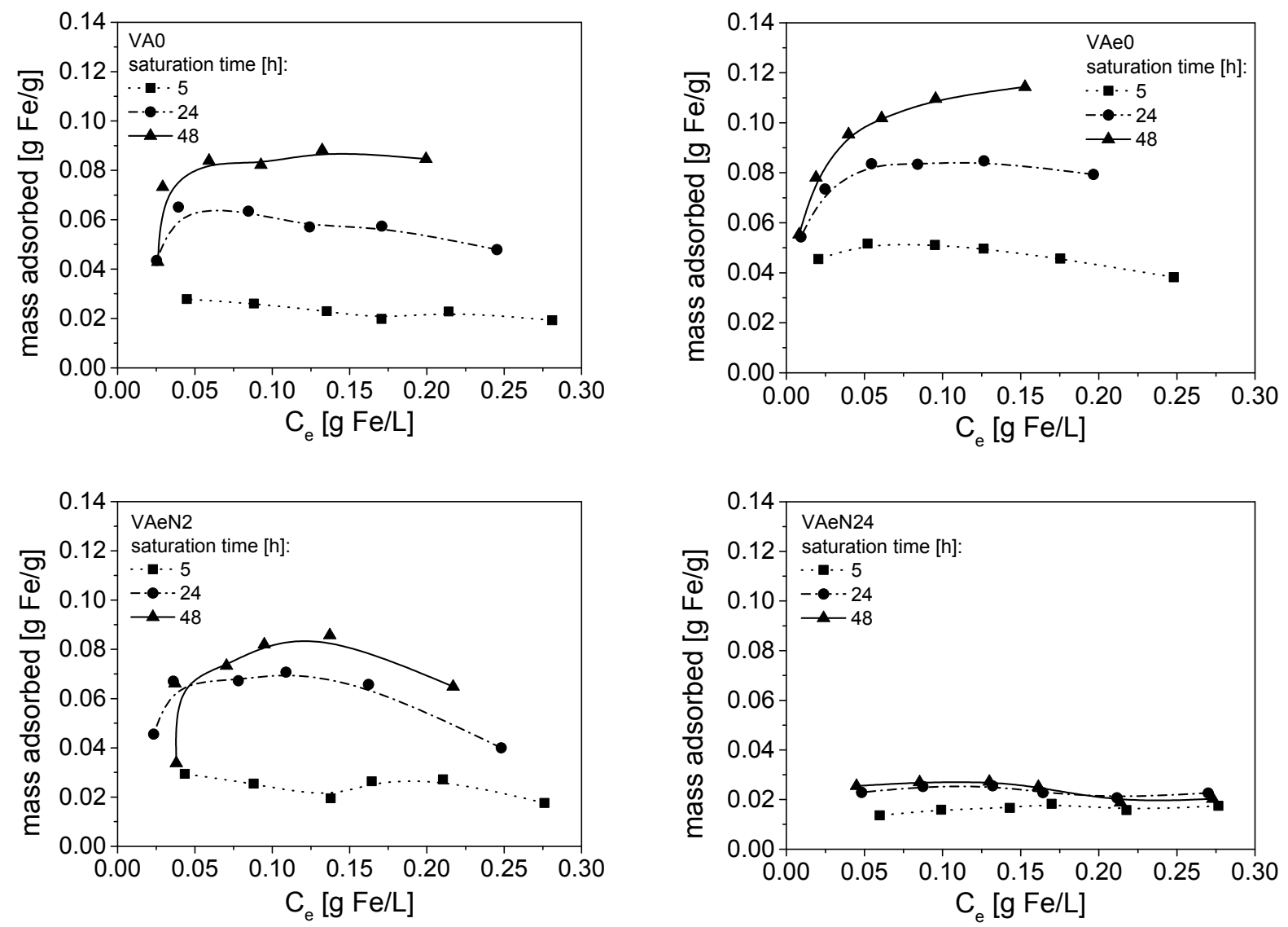

Fig. 4 Adsorption isotherms obtained on raw (VA0), expanded (VAe0) and acid treated (VAeN2, VAeN24) vermiculites.

$\mathrm{Fe}^{3+}$ was measured at 5, 24 and $48 \mathrm{~h}$. It was observed that equilibrium was not reached. The amount of $\mathrm{Fe}^{3+}$ adsorbed on raw and expanded vermiculite and also on the sample treated with acid for $2 \mathrm{~h}$ is increasing in consecutive measurements. It was also demonstrated (Fig. 4, high concentration range for the samples VA0, VAe0, VAeN2) that adsorption strongly depends on initial concentration of adsorbate. Surprisingly, in almost all experiments increase of initial iron concentration resulted in decreased content of adsorbed $\mathrm{Fe}^{3+}$. It should be stressed that each batch contained constant volume of buffering solution. Nevertheless, it should be taken into account that dissolved $\mathrm{Fe}^{3+}$ salt made significant contribution to ionic strength of the mixture. Thus, hydrolysis of $\mathrm{Fe}^{3+}$ cannot be excluded and may influence adsorption mechanism.

It was reported before that vermiculites are characterized with high adsorption properties (Bergaya et al., 2006; Abollino et al., 2008; Abollino et al., 2007) and adsorption mechanism is determined by cation exchange capacity. However, for such metal cations as $\mathrm{Cu}^{2+}$ or $\mathrm{Ni}^{2+}$ it was proven using X-ray absorption fine structure (EXAFS) spectroscopy and $\mathrm{X}$-ray absorption near edge spectroscopy (XANES) that inner-sphere and outer-sphere complexes are formed and adsorption takes place on the edges of vermiculite (Furnare et al., 2005; Yang et al., 2011). On the other hand, Scheinost and Sparks (Scheinost and Sparks, 2000) suggested that $\alpha$-type (metastable) metal hydroxides of $\mathrm{Co}$ and $\mathrm{Ni}$ were formed in the presence of the minerals such as montmorillonite and vermiculite. Surface precipitates may not be attached to the sorbent and $\mathrm{Ni}$ and Co-containing precipitates were formed within short reaction times (minutes to days). Described phenomenon was observed even when the calculated surface coverage was below a monolayer, and the $\mathrm{pH}$ was below saturation with respect to the known solubility products (solubility constants) of $\beta$-type hydroxides. As a result formation of a phyllosilicate with one or two silica sheets sandwiching a metal hydroxide sheet can be observed. Furthermore, easy formation of Al- or Fe- hydroxy interlayers (chlorite-like structures) in laboratory conditions was claimed by several authors (Carstea, 1968; Sawhney, 1968; Saha and Inoue, 1998), although time required for the reaction was relatively longer (days to weeks). All species that participate in adsorption mechanism are presented in Figure 5. 


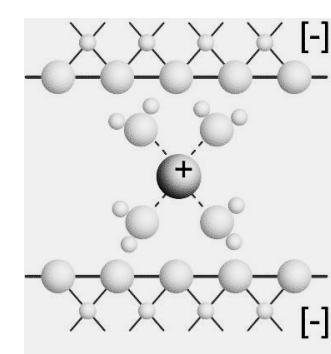

ion exchange

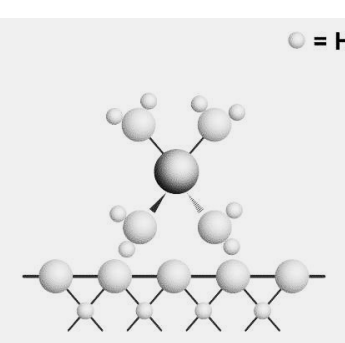

outer sphere complex

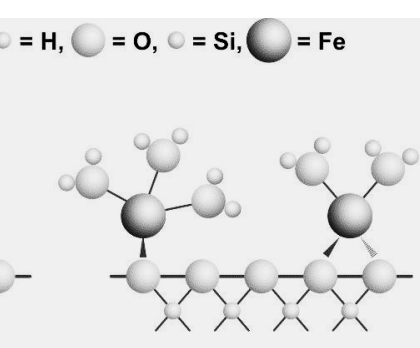

inner sphere complexes

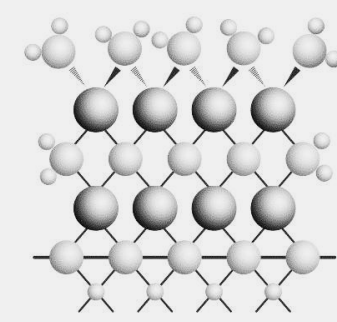

surface

precipitation

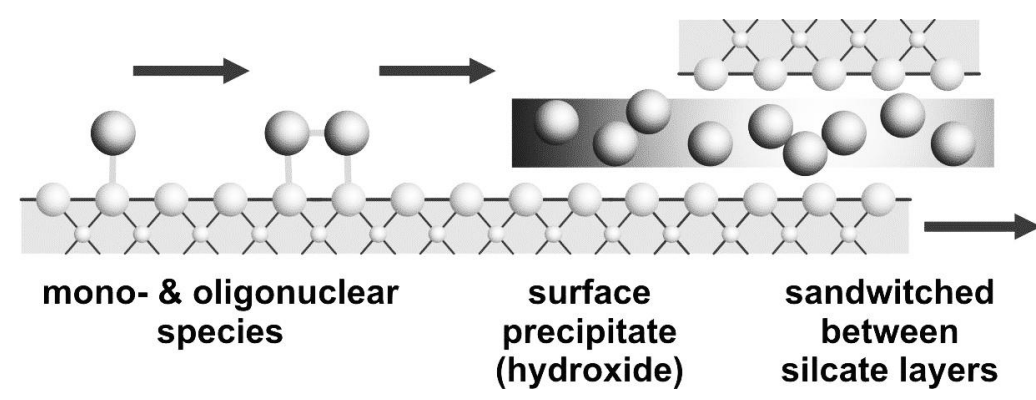

Fig. 5 Species of proposed adsorption mechanisms on vermiculite-based adsorbents.

Additional data support suggested mechanism. Typically CEC of vermiculites is in the range of 130$210 \mathrm{meq} / 100 \mathrm{~g}$. Thus, one can expect that maximum amount of metal cations exchanged would not be higher than $2.1 \mathrm{mmol}$ of positive charge per $1 \mathrm{~g}$. However, results obtained for 4 different vermiculites (Fig. 6) are equal: 0.912-2.730 $\mathrm{mmol}[+] / \mathrm{g}$ after $5 \mathrm{~h}$, $1.365-4.512 \mathrm{mmol}[+] / \mathrm{g}$ after $24 \mathrm{~h}$ and 1.467-6.123 $\mathrm{mmol}[+] / \mathrm{g}$ after $48 \mathrm{~h}$. Only in the case of acid treated sample VAeN24 calculated values do not exceed potential cation capacity. But it should be stressed that in acid treated samples CEC is lower due to removal of octahedral sheet and reduced layer charge.

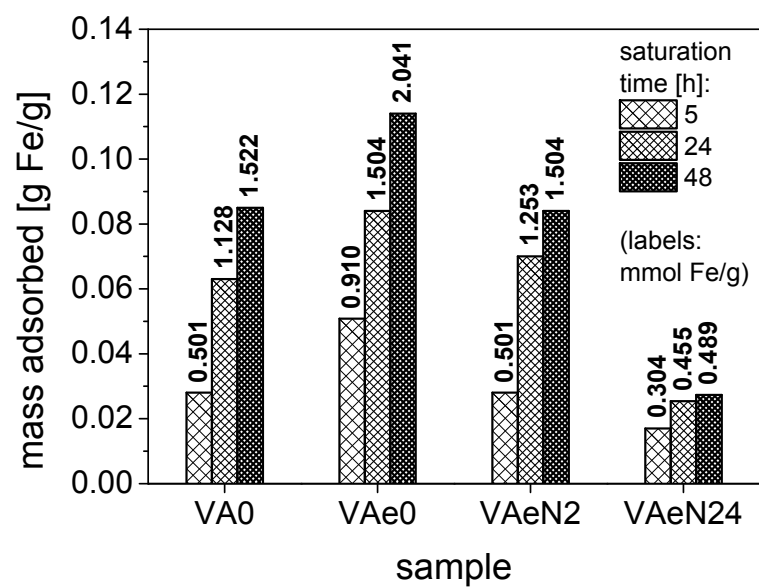

Fig. 6 Maximum adsorption capacities towards $\mathrm{Fe}^{3+}$ obtained on raw (VA0), expanded (VAe0) and acid treated (VAeN2, VAeN24) vermiculites.

\subsection{CHARACTERIZATION OF SPENT ADSORBENTS}

Characterization of spent adsorbents was performed for the samples digested in adsorbate solution for $48 \mathrm{~h}$ at concentration $0.0054 \mathrm{~mol} \mathrm{Fe}{ }^{3+} / \mathrm{L}$ (sample names VAxFe1). XRD studies confirmed that modified adsorbents structure has been altered upon adsorption process. Diffraction patterns in Figure 7 revealed that expanded vermiculite $(\mathrm{VAe} 0)$ which consisted of the mixture of domains with 0,1 and 2 water layers in layered structure was transformed successfully into vermiculite phase with two-one layer water and $\mathrm{Fe}^{3+}$ cations intercalated in interlayer space.

In the case of expanded and additionally acid treated sample VAeN2 changes were noticeable mostly in the range of basal reflections. Intercalation of $\mathrm{Fe}^{3+}$ occurred and peak associated with the presence of 2 layers of water appeared. However the structure reconstruction was not as spectacular as for expanded material. Phases of mica-like phase with no water molecules in the interlayer can be distinguished and they are overlapping with vermiculite reflections. Intercalation of cations was probably inhibited due to reduced layer charge as a result of acid treatment. It cannot be excluded that amorphous silica formed as a result of acid treatment, also hinders intercalation and adsorption process.

On the contrary, in raw vermiculite it is difficult to observe any changes - basal reflections remain unaffected. This is understandable since $\mathrm{Mg}^{2+}$ cations give rise to the same arrangement of water molecules as $\mathrm{Fe}^{3+}$. The only change observed was decrease of intensity of peaks between 10 and $35^{\circ} 2 \theta$. Calculated basal spacings are shown in Table 2 . 

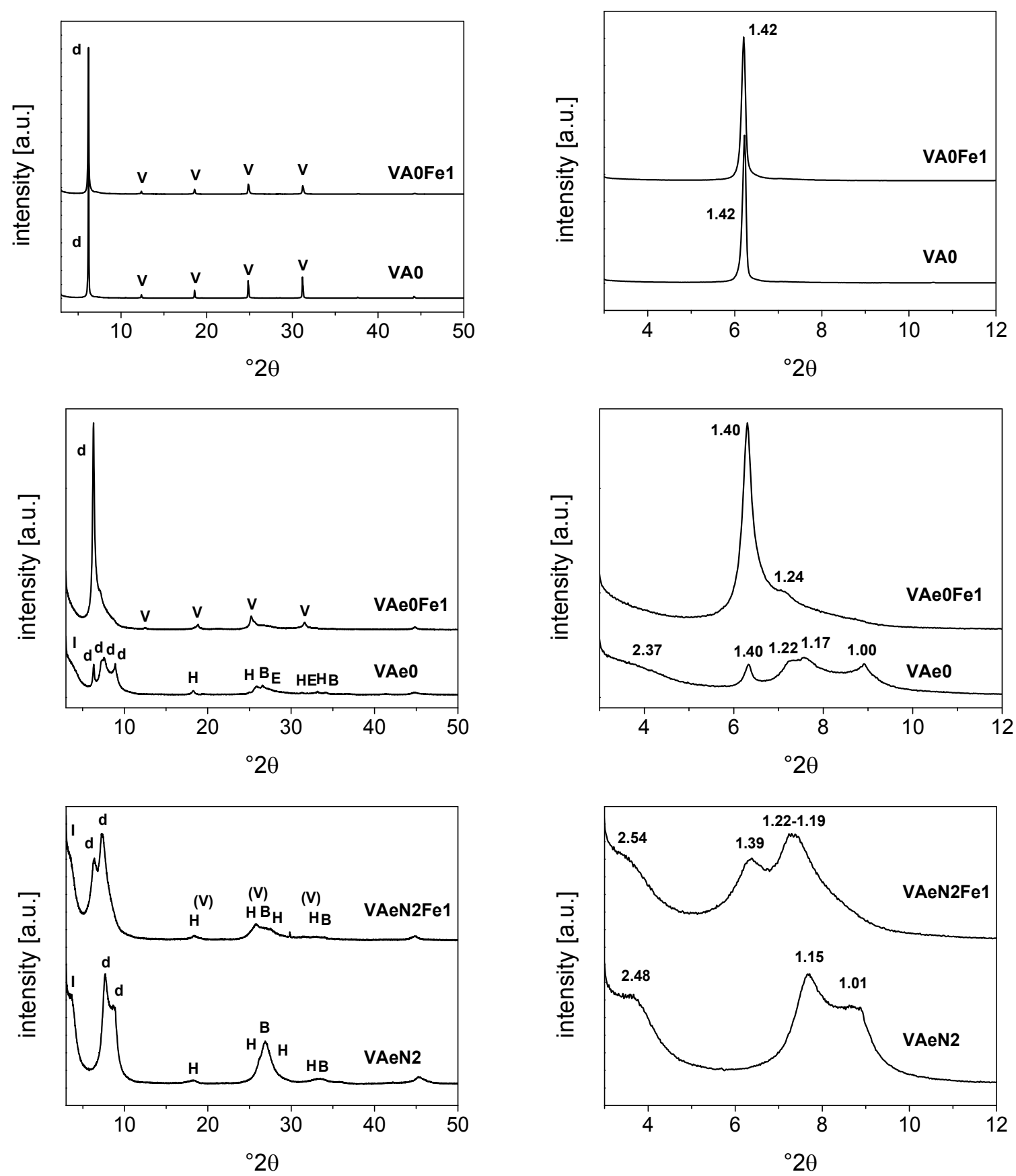

Fig. 7 XRD patterns of spent vermiculite-based adsorbents (VAxFe1); I- interstratified phase, $\mathrm{H}$ - hydrobiotite, $\mathrm{B}$ - biotite, $\mathrm{V}$ - vermiculite, $\mathrm{E}$ - enstatite, $\mathrm{d}$ - basal reflections.

Table 2 Interlayer distances of spent vermiculite-based adsorbents (VAxFe1).

\begin{tabular}{c|c|c|c|c|c}
\hline sample name & $\mathrm{d}[\mathrm{nm}]$ & $\mathrm{d}[\mathrm{nm}]$ & $\mathrm{d}[\mathrm{nm}]$ & $\mathrm{d}[\mathrm{nm}]$ & $\mathrm{d}[\mathrm{nm}]$ \\
\hline VA0Fe1 & - & 1.42 & - & - & - \\
VAe0Fe1 & - & 1.40 & 1.24 & - & - \\
VAeN2Fe1 & 2.54 & 1.39 & 1.22 & 1.19 & - \\
\hline & $\begin{array}{c}\text { inter- } \\
\text { stratification }\end{array}$ & $\begin{array}{c}\text { 2 layers of water } \\
\mathrm{Mg}^{2+} / \mathrm{Fe}^{3+}\end{array}$ & inter-stratification & $\begin{array}{c}\text { layer of water } \\
\mathrm{Mg}^{2+} / \mathrm{Fe}^{3+}\end{array}$ & $\begin{array}{c}0 \text { layers of water } \\
\mathrm{H}_{3} \mathrm{O}^{+}\left(\mathrm{K}^{+}\right)\end{array}$ \\
\hline
\end{tabular}


Furthermore, it was impossible to identify precipitation products such as iron oxides/hydroxides in any of studied samples after adsorption because they are characterized with low crystallinity and a small mass compared to the adsorbents.

\section{CONLUSIONS}

In presented work it was shown that vermiculitebased adsorbents have great potential in application of water and wastewater purification. Modifications such as expanding or acid treatment are beneficial for the adsorption, however in the latter case mild conditions are preferred. Further studies are necessary to evaluate the influence of acid treatment for removal contaminants such as dyes or pesticides (in general organic molecules). In designing of suitable adsorbent it should be taken into account that heavy metals usually are accompanied by other contaminants.

Higher efficiency of purification can be achieved in a combination of batch or semi-batch mode with column mode. Semi-batch and batch modes perform better with higher concentrated solutions, thus they would be used as a pretreatment unit, and the process would be then accomplished in column which work is satisfactory with relatively low concentrated solutions. Batch mode is less desired option than semi-batch, because additional separation equipment is required before entering the column.

It was shown that obtained adsorption capacities are higher than typically measured cation exchange capacities. Thus, we can expect that formation of inner and outer sphere complexes as well as surface precipitates and hydroxyl interlayers may contribute in the adsorption mechanism.

The structure of modified samples was altered significantly. Expanded material was reconstructed into vermiculite phase and acid treated sample was intercalated with $\mathrm{Fe}^{3+}$ cations. However, it was impossible to identify $\mathrm{Fe}^{3+}$ precipitates such as oxide or hydroxide phases.

\section{ACKNOWLEDGEMENTS}

Authors acknowledge the Polish Ministry of Science for financial support in the frame of project NN507 426939. The research was carried out with the equipment purchased thanks to the financial support of the European Regional Development Fund in the framework of the Polish Innovation Economy Operational Program (contract no. POIG.02.01.00-12023/08). Authors would like to thank Rominco Polska Sp. z o.o. for providing starting material for presented studies.

\section{REFERENCES}

Abate, G., dos Santos, L.B.O., Colombo, S.M. and Masini, J.C.: 2006, Removal of fulvic acid from aqueous media by adsorption onto modified vermiculite. Applied Clay Science, 32, 261-270. DOI: $10.1016 /$ j.clay.2006.02.004

Abollino, O., Giacomino, A., Malandrino, M. and Mentasti, E.: 2007, The Efficiency of Vermiculite as Natural
Sorbent for Heavy Metals. Application to a Contaminated Soil. Water Air Soil Pollution, 181, 149-160. DOI: 10.1007/s11270-006-9286-8

Abollino, O., Giacomino, A., Malandrino, M. and Mentasti, E.: 2008, Interaction of metal ions with montmorillonite and vermiculite. Applied Clay Science, 38, 227-236.

DOI: $10.1016 /$ j.clay.2007.04.002

Argüelles, A., Khainakov, S.A., Rodríguez-Fernández, J., Leoni, M., Blanco, J.A. and Marcos, C.: 2011, Chemical and physical characterization of ironintercalated vermiculite compounds. Physics and Chemistry of Minerals, 38, 569-580. DOI: 10.1007/s00269-011-0429-0

Bergaya, F., Lagaly, G., Vayer, M.: 2006, Cation And Anion Exchange, in: Bergaya, F., Theng, B.K.G., Lagaly, G. (Eds.): Handbook of Clay Science, Elsevier, pp. 979.

Carstea, D.D.: 1968, Formation of hydroxy-Al and -Fe interlayers in montmorillonite and vermiculite: Influence of particle size and temperature. Clays and Clay Minerals, 16, 231-238. DOI: $10.1346 / C C M N .1968 .0160305$

Chmielarz, L., Kowalczyk, A., Michalik, M., Dudek, B., Piwowarska, Z., Matusiewicz, A.: 2010, Acidactivated vermiculites and phlogophites as catalysts for the DeNOx process, Applied Clay Science, 49, 156-162. DOI: 10.1016/j.clay.2010.04.020

Chmielarz, L., Kuśtrowski, P., Piwowarska, Z., Dudek, B., Gil, B. and Michalik, M.: 2009, Montmorillonite, vermiculite and saponite based porous clay heterostructures modified with transition metals as catalysts for the DeNOx process. Applied Catalysis: B-Environmental, 88, 331-340. DOI: 10.1016/j.apcatb.2008.11.001

Chmielarz, L., Wojciechowska, M., Rutkowska, M., Adamski, A., Węgrzyn, A., Kowalczyk, A., Dudek, B., Boroń, P., Michalik, M. and Matusiewicz, A.: 2012, Acid-activated vermiculites as catalysts of the DeNOx process. Catalysis Today, 191, 25-31. DOI: 10.1016/j.cattod.2012.03.042

Crini, G.: 2006, Non-conventional low-cost adsorbents for dye removal: A review. Bioresource Technology 97, 1061-1085. DOI: 10.1016/j.biortech.2005.05.001

da Fonseca, M.G., Almeida, R.K.S., Arakaki, L.N.H., Espinola, J.G.P. and Airoldi, C.: 2006, Vermiculite as a useful host for guest cyclic aliphatic amine intercalation, followed by cation adsorption. Colloids and Surfaces A: Physicochemical and Engineering Aspects, 280, 39-44. DOI:10.1016/j.colsurfa.2006.01.020

da Fonseca, M.G., de Oliveira, M.M., Arakaki L.N.H., Espinola, J.G.P. and Airoldi, C.: 2005, Natural vermiculite as an exchanger support for heavy cations in aqueous solution. Journal of Colloid and Interface Science, 285, 50-55. DOI: 10.1016/j.jcis.2004.11.031

Downs, R.T.: 2006, The RRUFF project: an integrated study of the chemistry, crystallography, Raman and infrared spectroscopy of minerals. In: Program and abstracts of the 19th general meeting of the International Mineralogical Association in Kobe, Japan. O03-13

El-Bayaa, A.A., Badawy, N.A. and Abd AlKhalik, E.: 2009, Effect of ionic strength on the adsorption of copper and chromium ions by vermiculite pure clay mineral. Journal of Hazardous Materials, 170, 1204-1209. DOI: 10.1016/j.jhazmat.2009.05.100 
Forgacs, E., Cserhati, T. and Oros, G.: 2004, Removal of synthetic dyes from wastewaters: A review. Environment International, 30, 953-971.

DOI: 10.1016/j.envint.2004.02.001

Fu, F. and Wang, Q.: 2011, Removal of heavy metal ions from wastewaters: A review. Journal of Environmental Management, 92, 407-418. DOI: 10.1016/j.jenvman.2010.11.011

Furnare, L.J., Vailionis, A. and Strawn, D.G.: 2005, Polarized XANES and EXAFS spectroscopic investigation into copper(II) complexes on vermiculite. Geochimica et Cosmochimica Acta, 69, 5219-5231. DOI: 10.1016/j.gca.2005.06.020

Gordeeva, L.G., Moroz, E.N., Rudina, N.A. and Aristov, Yu, I.: 2002, Formation of Porous Vermiculite Structure in the Course of Swelling. Russian Journal of Applied Chemistry, 75, 357-361. DOI: $10.1023 / \mathrm{A}: 1016165915362$

Helsen, J.A.: 1975, The orientation of the principal axes system of the electric field gradient in $\mathrm{Fe}$ (III) vermiculite determined by Mössbauer spectroscopy. Clays and Clay Minerals, 23, 332-334. DOI: $10.1346 / C C M N .1975 .0230411$

Machado, L.C.R., Lima, F.W.J., Paniago, R., Ardisson, J.D., Sapag, K. and Lago, R.M.: 2006, Polymer coated vermiculite-iron composites: Novel floatable magnetic adsorbents for water spilled contaminants. Applied Clay Science, 31, 207-215.

DOI: 10.1016/j.clay.2005.07.004

Malandrino, M., Abollino, O., A.Giacomo, A., Aceto, M. and Mentasi, E.: 2006, Adsorption of heavy metals on vermiculite: Influence of $\mathrm{pH}$ and organic ligands, Journal of Colloid and Interface Science, 299, 537546. DOI: $10.1016 /$ j.jcis.2006.03.011

Marcos, C., Arango, Y.C., Rodriguez, I.: 2009, X-ray diffraction studies of the thermal behavior of commercial vermiculites, Applied Clay Science, 42, 368-378. DOI: 10.1016/j.clay.2008.03.004

Marcos, C. and Rodríguez, I.: 2010, Expansion behaviour of commercial vermiculites at $1000{ }^{\circ} \mathrm{C}$, Applied Clay Science 48, 492-498.

DOI: $10.1016 /$ j.clay.2010.02.012

Saha, U.K. and Inoue, K.: 1998, Hydroxy-interlayers in expansible layer silicates and their relation to potassium fixation, Clays and Clay Minerals, 46, 556566. DOI: 10.1346/CCMN.1998.0460509

Sawhney, B.L.: 1968, Aluminum interlayers in layer silicates. Effect of $\mathrm{OH} / \mathrm{Al}$ ratio of $\mathrm{Al}$ solution, time of reaction, and type of structure, Clays and Clay Minerals, 16, 157-163.

DOI: 10.1346/CCMN.1968.0160206
Scheinost, A.C. and Sparks, D.L.: 2000, Formation of layered single- and double-metal hydroxide precipitates at the mineral/water interface: A multiplescattering XAFS analysis, Journal of Colloid and Interface Science, 223, 167-178. DOI: $10.1006 /$ jcis. 1999.6638

Sumathi, K.M.S., Mahimairaja, S. and Naidu, R.: 2005, Use of low-cost biological wastes and vermiculite for removal of chromium from tannery effluent, Bioresource Technology 96, 309-316. DOI: 10.1016/j.biortech.2004.04.015

The EU Water Framework Directive - integrated river basin management for Europe, http://ec.europa.eu/environment/water/waterframework/index en.html, (available: 25.11.2012).

Vieira dos Santos, A.C. and Masini, J.C.: 2007, Evaluating the removal of $\mathrm{Cd}(\mathrm{II}), \mathrm{Pb}(\mathrm{II})$ and $\mathrm{Cu}(\mathrm{II})$ from a wastewater sample of a coating industry by adsorption onto vermiculite, Applied Clay Science, 37, 167-174. DOI: 10.1016/j.clay.2006.12.009

Yang, S.,Sheng,G.,Tan, X., Hu, J., Du, J., Montavon, G. and Wang, X.: 2011, Determination of $\mathrm{Ni}(\mathrm{II})$ uptake mechanisms on mordenite surfaces: A combined macroscopic and microscopic approach, Geochimica et Cosmochimica Acta, 75, 6520-6534. DOI: 10.1016/j.gca.2011.08.024

Yu, X., Wei, C., Ke, L., Hu, Y., Xie, X. and Wu, H.: 2010, Development of organovermiculite-based adsorbent for removing anionic dye from aqueous solution, Journal of Hazardous Materials, 180, 499-507. DOI: 10.1016/j.jhazmat.2010.04.059

Zhao, M., Tang, Z. and Liu, P.: 2008, Removal of methylene blue from aqueous solution with silica nano-sheets derived from vermiculite, Journal of Hazardous Materials, 158, 43-51. DOI: $10.1016 /$ j.jhazmat.2008.01.031 